\title{
A REVIEW OF SOME RECENT PAPERS UPON THE LOSS OF THE FEELING OF REALITY AND KINDRED SYMPTOMS.
}

\author{
BY DR, AUGUST HOCE, \\ McLean Hospital, Waverley, Mass.
}

Although the symptoms which may be comprised under this heading are by no means infrequent in psychasthenic states and in various psychoses, they have received relatively little attention until quite recent years. In the textbooks on psychiatry with the exception of that of Wernicke, whose work is a perfect mine for everyone who wishes to study abnormal mental manifestations, they are scarcely mentioned or are buried, often to such a degree as to be almost unrecognizable, in the general account of hypochondriacal delusions. And yet the French literature contains a number of early studies, $e_{*} g$., the report of Krieshaber ${ }^{1}$ and some articles of Cotard."

Recently a number of studies have appeared which deal at some length with these symptoms. What is common to all the cases reported is the loss of the feeling of reality within one or another field of experience, either that relating to the outside world or to the body, or to the individual's own activities or thoughts." All these symptoms are present in spite of the fact that there exists neither a real sensory defect (some exceptions will be noted later) nor any agnosia.

We will briefly consider the cases recently reported. The patient of Foerster complained of being unable to feel the various parts of her body. This extended not only to the limbs, trunk, and head, but, when speaking of the respective sensations of sight, hearing, and taste, she said she could not feel her eyes, ears, or tongue. She claimed

${ }^{1}$ Krieshaber, quoted by Störring in his Vorlesungen über Psychopathologie, 1900, p. 286, and by James, Principles of Psychology, Vol. I., p. 377 .

'Cotard: 'Du délire des negations,' and 'Perte de la vision mentale dans la mélancolie anxieuse,' Etudes sur les Maladies Cérébrales et Mentales, Paris, I8gr.

s Wernicke has for the sake of simplicity introduced into peychiatry special terms for these sets of experiences and speaks of the allopsyche, somatopsyche, and autopsyche.

- Foerster, 'Ein Fall von elementarer allgemeiner Somatopsychose (Afunktion der Somatopsyche),' Monatsschrift für Psychiatrie und Neurologie, Vol. XTV., p. r8g. 
that when lying in bed she did not know what position she was in. When the wind blew upon her face or she was touched, the parts thus influenced became more real. ${ }^{1}$ In regard to the outside world she said that she could not recognize anything, that the eyes did not reach out, that everything looked veiled, that she could not hear clearly, that she could not 'take in' odors, that the food did not taste as it used to, touch seemed dull, pain 'not as it used to be.' She had the same sense of unreality when she was asked to name objects by handling them. In regard to her own mental processes she said that she had ' no thoughts' and that she was unable to represent any impressions to herself. "While I look at a thing I know how it looks, when I close my eyes it is gone." " As is very common, especially in milder cases, this patient had a feeling of indifference towards everything. At the height of the disorder she expressed a very decided loss of the feeling of self (depersonalization). In addition she presented an inactivity and a state of depression, perplexity and fear.

It will be seen that this case resembles in many ways that of Krieshaber. K.'s patient also spoke of his body as non-existing, said that things looked far away, that his ears seemed stopped up, and that he felt as if he were a different being. This man, however, also showed a symptom which seems to be rare, but which $I$ have been able to observe in a very grave case of this sort. To him things looked flat, had no relief. I may add that in my case this was associated with fleeting errors in estimating distances. K.'s case showed also a loss of the feeling of activity.

An interesting and graver case has been reported by Alter. ${ }^{3}$ The patient not only complained that his body was not real but that it constantly changed, ' the moment I change my position the body changes.' He spoke of it as being in particles, not put together right, etc. The external world was unreal and moreover changed. "Every time I look at things they are changed; I constantly get into different relations with my surroundings." And he spoke, for example, of the house as being mixed up, the corridor wrongly attached, or when

In some cases of my own the very opposite took place; touching or rabbing precipitated the feeling of unreality for the parts of the body in question.

8 The feeling of unreality in regard to one's own mental processes may be very marked. I have the notes of a patient who said that at no time did any thoughts come into her mind, and that her mind only bad a content when someone talked to her, 'when the person goes, the thoughts go.' Another patient claimed that she only had thoughts in her mind so long as she spoke.

'Alter, 'Ueber eine seltenere Form geistiger Störnng,' Monatsschrift für Psychiatrie und Neurologie, Vol. XIV., p. 246. 
he returned from a walk he said on one occasion: 'It seems as' if ' $I$ had been away for eternity, things look so different.' He also had an absence of the feeling of activity for his own actions, but not a sense of unreality in regard to his thoughts. Evidently as the result of this feeling of change produced by every movement, he sometimes lay motionless in forced positions, resisting every interference (a condition occasionally observed in such patients, but to be sharply differentiated from other, though superficially similar, states of akinesis). On some occasions he went so far as to definitely deny the identity of objects. This trait may be very much more marked in some cases; it was first described by Cotard under the term of détire de négation.

In a patient of Pick ${ }^{1}$ the depersonalization was very marked. She complained that she had 'no consciousness,' that she did not know herself, that she was ' not alive,' and in the foreground was an absence of the feeling of activity. "It is not I who thinks or acts." She also said: 'I have no memory.' Aside from this there was no decided expression of unreality of the body, but the external world appeared strange. She said she saw things 'far away,' 'erstarrt,' 'the vision is cut off.' She complained of absence of hunger. She was depressed and said she felt no interest in anything.

Juliusberger ${ }^{2}$ reports a milder case who complained that things looked strange and lifeless. She appeared strange to herself, and her own writing and voice seemed.strange to her. She said she was unable to represent to herself how things looked or tasted, that she could not realize the flight of time, that she felt indifferent, and for a time she claimed that her sense of hunger and thirst were absent.

This entire symptom complex, although scarcely in its gravest form, is evidently well known to Janet, and in his recent works ${ }^{3}$ much may be found on the subject. He gave a brief review of this work, at a recent visit to this country." In this article he speaks, e. $g .$, of an epileptic who had a transient attack in which he had an abnarmal feeling about the reality of the visible world, and doubt about the existence of things, a state which was associated with aboulia. Another case which resembled that of Pick said 'It is not I who eats, speaks, works,' 'I lack something to give me real existence.'

'Pick, 'Zur Pathologie des Ich-Bewusstseins,' Archiv für Psychiatrie, Vol. 38, p. 22 .

'Juliusherger, 'Ueber Pseudomelancholie,' Monatsschrift für Psych. und' Neurol., January, 1905.

'Janet, Névroses et Idées Fixes, Paris, 1898; Les Obsessions et la' Pyychasthénie, Paris, Igo3.

'Janet, 'The Psycholeptic Crises,' Boston Medical and Surgical Jour. January 26,1905 . 
She also claimed that she could not remember anything. There was no definite feeling of unreality in regard to her body, and the abnormal feelings associated with the recognition of the outside world were only indicated. "It is dull before my eyes." This patient also said that she had lost all idea of time. But Janet also relates a case in which the body especially appeared altered to the patient. She had attacks in which she felt that she grew smaller and totally different. At one time she stopped eating because her mouth was 'gone.' Again her hands and feet seemed to her no longer to be a part of herself, 'a dream hand.' She said that things seemed to be done, to be seen and touched, not to be lived with. She also complained of lack of interest.

The objective examinations which were-made of these various cases revealed very little. The acuteness of the various sensations was never altered, except in the case of Alter, who found a unilateral diminution for the appreciation of roughness in his case, a symptom which he attributes to hysteria. I myself found on one day with very careful examination a slight difference in touch sensation on the two legs. Various investigators have found the field of vision normal, the color perception intact. Foerster examined into the visual memory; he found it normal. It may here be added that in general the memory is not interfered with even in the cases who claim that they cannot remember, just as there is no real slowness in thinking when the patients claim they have no thoughts. Foerster found the ability to localize skin impressions to be normal. Janet, who made extensive and very careful tests in his cases, found no disorder of cutaneous, muscle, or visceral sensibility, but a certain disposition on the part of the patient to ' neglect agreeable or painful impressions.' I have repeatedly noted that patients who subjectively complain of lack of interest state that pinpricks do not seem so sharp as normally, though there is no objectively demonstrable diminution of pain sensation. Of interest are the results of Alter. The examination of various kinds of sensation gave at times perfectly normal results; again, at the same interview, anæsthesias or analgesias were found, especially when the attention was drawn to these sensations. Sometimes passive motions were correctly recognized and correctly imitated with the corresponding limb, again both were very poor. Sometimes cutaneous sensations were correctly localized, again very poorly. In a similar case of my own I found fleeting inability to localize cutaneous impressions and to recognize passive motions. It was in this same patient that, as I have indicated above, fleeting disorders of estimating distances by sight were noted. The impression left was that the perplexity alone did 
not explain these disorders. While, then, it is impossible to demonstrate objectively any sensory disorders, it may nevertheless be the case that fleeting changes may be present in grave cases in which the somatopsychic alterations are the most marked, but further studies are needed.

As to the explanation of these phenomena, it is scarcely possible to come to any definite conclusions as yet. Pick, who in his first paper ${ }^{1}$ called attention to the same transient states in epileptics as Janet reports, simply spoke of alterations in the feeling of recognition (the Bekanntheitsgefiuhl of Volkelt). Janet, who calls these phenomena psycholeptic crises, is inclined to oppose what he calls the simple explanation, that in some way these symptoms have something to do with disorders of organic sensations, because his careful search for alteration in this direction revealed nothing. What he regards as the common factor in these cases is a peculiar sense of incompleteness (sentiment d'incomplétude) in regard to perceptions, emotions, and actions, 'the mind does not carry out its processes to their normal completion.' He assumes that mental operations can manifest themselves in two different ways. They may bear ' upon abstract ideas, general ideas, imaginary conceptions and representations, and even upon the reproduction of past events.' On the other hand they may 'bear upon events which are present and real and produce a knowledge of complex events which are actually taking place in the universe at the moment; also where they produce reactions in us which are likewise perfectly real acts, that is to say, acts capable of determining modifications in the world as it exists.' While ordinarily these two sets of phenomena are regarded as identical, Janet claims that they differ in complexity and in the nervous tension which they require, the former requiring less tension, because they represent merely repetitions or syntheses, previously achieved, and because they deal with abstract elements, few in number and extremely simplified, the latter requiring greater tension because new syntheses and complex elements are constantly required and a constant adaptation to new situations. He concludes, therefore, that a lowering of cerebral activity would explain these phenomena. It should be added that Janet regards this merely as an hypothesis and urges that most stress be laid on the observation of facts. Whatever one might say about this hypothesis, it is not clear how it could explain the somatopsychic part of the symptom complex which is sometimes the most prominent feature. The fact that the most habitual sensations, those which inform us about the

'Pick, 'Zur Pathologie des Beiranntheitsgefihls (Bekanntheitsqualität),' Neurologisches Centralblatt, 1903, Vol. XXII, p. 2. 
various parts of our body, are no longer correctly valued (sometimes only parts of the body are thus excluded from correct valuation) is certainly not in accord with such an hypothesis.

Foerster, Alter and Juliusberger stand in their explanations on the ground of Wernicke and above all of Storch." S. claims that the feeling of the reality of external objects and the projection into space depend upon the association of muscle sensations with sense perceptions. Foerster, therefore, thinks that the change is to be found primarily in a disorder of the consciousness of the body, an insufficient valuation of organic sensations, and secondarily in a disorder of the consciousness of the external world. The fact that his patient had a feeling of unreality about her own ideas he explained on the ground that these consist of memories of sense impressions and organic sensations. There is no doubt but that this explanation has much in its favor. Above all, it takes into account the frequent association of the somatopsychic and allopsychic changes, and it would also be in harmony with the fact that these symptoms present a close relation to emotional changes which latter may both succeed or precede (see below) them. Janet's claim that we find no real demonstrable disorders of organic sensations, even if it should prove to be absolutely correct, would be no argument against such an hypothesis, since such changes would have to be regarded like the agnosias as association disorders, and not as anæsthesias.

I shall refrain from going into the clinical side of these disorders; it may only be mentioned that according to Janet and Pick they occur frequently in epilepsy; according to Janet and Storch in psychasthenic and neurasthenic conditions. According to Janet they often form the basis upon which phobias and compulsive thinking arise. Storch states that they occur often in melancholia. In my experience they may be found in the various forms of depression, especially in the socalled involution melancholias; also in the depressions of manic de-pressive insanity where they may vitiate the prognosis; they may occur in the depressions of dementia præcox and general paralysis, though they may sometimes appear as independent affections. In general it may be said that they seem to be closely related to the depressive symptom complex (especially in its apprehensive form) not only in the sense that depression and apprehension follow them, but also in sense that the symptom complex here discussed may precede (or in manic depressive insanity replace) the melancholic syndrome.

'Storch, 'Muskelfunction und Bewusstein,' Grenzfragen des Nervenund Seelenlebens, No. $\mathrm{X}$., Wiesbadea, J. F. Bergmann, rgor. 
After $I$ had sent off the foregoing review two articles have appeared which deal with the same subject, and it may be of interest to add these here.

The first article is by Deny and Camus ("Sur une forme d'hypochondrie aberrante due à la perte de la conscience du corps,' Revue Neurologique, May 15, 1905). The authors report a case with very pronounced abnormalities who had had similar attacks before. The present one developed after a brief period of confusion. The feeling of unreality was very extensive. The patient complained that the whole body was changed. This extended to the various parts, the limbs, trunk, and head, and she often said she felt as if the body no longer existed, and that when lying in bed she could not feel where the linubs were except when she rubbed them. She had no feeling of hunger but much thirst, yet after drinking she felt as if she had not taken anything. She claimed that after she closed her mouth she did not know where her tongue was. When waking up in the morning she said she did not know how the night had passed (I have observed a few times that such people claim that their sleep is different from what it used to be, that it is not real sleep). In regard to the outside world she felt that everything looked unreal, that hearing was different, smell, taste, touch lost: "When I touch an object it is as if it were not I.' She said she was unable mentally to represent anything to herself. About her own acts she said, 'I do not feel it when I do anything,' and in general, 'I do not feel myself as before.' She complained of lack of affection towards her people, and of utter indifference. The general condition was one of agitation and depression. Like all other patients, she remained clear. Objectively no disorder of sensation could be demonstrated with the exception of a diminished pain appreciation, which as we have seen above is not uncommon. The authors decline, as we have done, to accept the hypothesis of Janet, and are in favor of that advanced by Storch and his followers.

The other article is a second contribution by Juliusberger. ${ }^{1} \mathrm{~J}$. reports briefly a case in which the feeling of unreality extended chiefly to the autopsychic activities, $i$. e., to her own thoughts. But she also claimed that she had two selves, that sometimes she felt the one, again the other. She spoke of one, the more positive one, as being in her heart or in her chest, where it was bound up and pined for freedom, desired to live, that it was from there that

'Zur Symptomatologie der Mclancholie,' Monatsschrift für Psychiatrie und Neurologie, May, 1905. 
the thoughts and desires came. The other self she said was a negative one, that it was in the head, and there observed everything like a third person, but that it had no thoughts. She also said, 'It thinks up there, but it isn't I who thinks.' Again, "I repeat word for word what I hear, but it doesn't seem to be I. *** It is as if one talked into a phonograph and it simply comes back. I don't hear, but I understand the sense." Or, she said that the thoughts had no connection with herself; or again, ' I have only a bodily feeling of myself, I have only a body.' This 'splitting of personality' J. wishes to explain by assuming a dissociation between the somatopsychic functions on the one hand, and the allo- and autopsychic on the other. He recalls Meynert and Wernicke, who regard the consciousness of the body, $i$. e., the sum total of all organic sensations, as the 'primary self' which stands as an ever constant complex against the the other contents of consciousness. In his further discussion J. trie's to show that in reality the somatopsyche, the consciousness of self, and the conscious will are one and the same, and claims that while sensations and perceptions represent the becoming conscious of the completed reaction toward stimuli, the actual process, the activity of the nervous system itself, also becomes conscious as feeling of activity, this being the result of organic sensations and therefore the function of the somatopsyche.

$J$. finally seems to assume that the difficulty in thinking which his patient expressed in various ways is identical with the retardation of thinking so frequently found in certain states of depression with which often no feeling of unreality is associated. He is inclined to attribute this symptom to the same sort of dissociation, and he promises to show that much in the depressive syndrome will have to be explained on a somatopsychic basis. In a footnote he adds that in the manic states practically the same principles will probably hold. It is well in this connection to call attention to the fact that at the end of his former article J. suggests that it would be well to study whether or not pseudomelancholias, by which he means depressions without obvious psychomotor retardation, differ from true melancholias, that is, depressions with psychomotor retardation, in the fact that in the former the organic sensations of motion or their memory pictures remain in the 'waking consciousness,' while in the latter 'they sink at times more or less into subconsciousness.' In other words, he is inclined to attribute the retardation of motion, as well as that of thinking, both of which constitute prominent symptoms of those depressions which belong in the group of manic depressive insanity, to disorders similar 
to that in the feeling of unreality sketched in the foregoing. Aside from the fact that $J$. brings no valid reason for this as yet, there exists much clinical evidence which seems to speak against such a view. Altogether it would seem wise not to generalize too soon in a field in which we still know comparatively little, a danger which Alter also has not avoided. However, in regard to J.'s point it is well to suspend judgment until we know what he has to say in the future article which he promises. 